\title{
POWER OF LEGISLATIVE BODIES TO PUNISH FOR CONTEMPT ${ }^{2}$
}

\section{(Continued)}

\section{Legal Basis of Contempt Power of Legislative Bodies}

It may be stated in general terms that the courts in this country and in England have practically without exception recognized the existence of the right of legislative bodies to protect their rightful privileges and to remove obstructions to the proper performance of their functions, by use of their contempt powers against offenders. The right in England has at times been stated to be a survival of an ancient judicial power supposed to have persisted in the two houses from the days when they sat together as the highest court of the realm, but, as has already been shown, the power seems not to have been exercised by the House of Commons until about the middle of the sixteenth century. But, whatever its origin, it is certain that, for more than a hundred years past, the right has been justified by the courts on both sides of the Atlantic on precisely the same ground,--that is, on the ground of necessity. This argument has not been more forcefully stated than by Lord Ellenborough, Chief Justice, in the case of Burdett v. Abbott, ${ }^{2}$ decided by the Court of King's Bench, in I8II, wherein he said:

"The privileges which belong to them [the Houses of Parliament] seem at all times to have been, and recessarily must be, inherent in them, independent of any precedent; it was necessary that they should have the most complete personal security, to enable them freely to meet for the purpose of discharging their important functions, and also that they should have the right of self-protection; I do not mean merely against acts of individual wrong; for poor and impotent indeed would be the privileges of Parliament, if they could not also protect themselves against injuries and af-

${ }^{2}$ The first installment of this article was published in 74 U. OF PA. I. REv. 69t (1926).

14 East 1, 137-138 (1811). 
fronts offered to the aggregate body, which might prevent or impede the full and effectual exercise of their parliamentary functions. . . . The right of self-protection implies, as a consequence, a right to use the necessary means for rendering such self-protection effectual. Independently, therefore, of any precedents or recognized practice on the subject, such a body must $a$ priori be armed with a competent authority to enforce the free and independent exercise of its own proper functions, whatever those functions might be."

This case was elaborately discussed. in the argument of counsel in the leading American case, ${ }^{3}$ decided ten years later, and the reasoning and to some extent the language of our court are substantially the same as that of Lord Ellenborough. At one point in the opinion the court says:

"If there is one maxim which necessarily rides over all others, in the practical application of government, it is, that the public functionaries must be left at liberty to exercise the powers which the people have intrusted to them. The interest and dignity of those who created them, require the exertion of the powers indispensable to the attainment of the ends of their creation."

And a little further on we find this application of his maxim to our legislative bodies:

"That a deliberate assembly, clothed with the majesty of the people, and charged with the care of all that is dear to them; composed of the most distinguished citizens, selected and drawn together from every quarter of a great nation; whose deliberations aire required by public opinion to be conducted under the eye of the public, whose decisions must be clothed with all that sanctity which unlimited confidence in their wisdom and purity can inspire; that such an assembly should not possess the power to suppress rudeness, or repel insult, is a supposition too wild to be suggested."

The same idea is at the foundation of practically all our state decisions and has many times been expressed with great

Anderson v. Dunn, 6 Wheat. 204 (U. S., 1821). 
force. The same ground of necessity has been recognized by all commentators on American constitutional law. Thus Chancellor Kent, writing of the power to punish for contempt, in I826, says:

"It is a power inherent in all legislative assemblies, and is essential to enable them to execute their great trusts with freedom and safety. And it has been frequently exercised, not only by Congress, but by the respective branches of the state legislatures, and may be considered as indisputably acknowledged and settled."

Story, writing in 1833 , recognizes that by the common law the power is inherent and indispensable, alike to courts and to legislative bodies. He then adds:

"Nor is the power to be viewed in an unfavorable light. It is a privilege, not of the members of either house; but, like all privileges of congress, mainly intended as a privilege of the people, and for their benefit."

\section{Effect of the Separation and Distribution of Powers OF GovernMENT}

From the foregoing quotations from decisions and authorities, it is clear that the power to punish for contempt is not a substantive power conferred upon legislative bodies by fundamental law, but is inherent and ancillary. It is not an end in itself but a means to an end, a part of the mechanism, so to speak, by which

- Take for example this extract from the Supreme Court of California, in 1866 :

"A legislative assembly, when established, becomes vested with all the powers and privileges which are necessary and incidental to a free and unobstructed exercise of its appropriate functions. These powers and privileges are not derived from the constitution; on the contrary, they arise from the very creation of a legislative body, and are founded upon the principle of selt-preservation. The Constitution is not a grant, but a restriction upon the power of the Legislature." Ex parte McCarthy, 29 Cal. 395, 403 (1866).

- I Kent's Commentaries, 236.

- I StORY on Const., 5th Ed. Secs. 845-849, pp. 612-622. For similar expressions, see COOLEY, CoNstitutional LIMITATIONS, 6th Ed., pp. 159-162; Rawle on the Constitution, ch. 4, p. 48; Cushing, Law \& Proc. of leg. Ass., 2d Ed. Sec. 655, p. 259. 
the legislative mill is cnabled to turn out its grist. It follows, therefore, that it was but slightly affected, if at all, by the gradual introduction, after the Revolution, of the doctrine of the separation of the powers of government. That doctrine, as Madison pointed out, is a "political doctrine" and not a technical rule of law, and the Supreme Court has never applied it rigidly. ${ }^{\top}$ But even a rigid application of it would not interfere with the proper exercise of the contempt power by legislative bodies, since it is an inherent power and exists as an aid to any legislative assembly in the performance of its legitimate functions. The only effect that the doctrine of separation has had upon the legislative bodies in this country has been to cause them to give up the exercise of most of the purely substantive judicial and executive powers they had previously exercised. For example, a legislative assembly cannot try a case involving the violation of the criminal laws of the state, except in so far as the act in question may have interfered with the rightful procedure of the assembly. Thus, if A assaults $B$, a member of the assembly, for words spoken in debate, he is guilty of two offenses, one the criminal offense of assault and battery, and the other a contempt of the assembly, with which it alone can deal. 8 To punish him for both is not double jeopardy. ${ }^{9}$ The latter is for the purpose of preventing obstructions of the House or further assaults on its members, the former to vindicate the laws of the land. As a result of the separation of the powers of government, all cases of the former class have been given up by the legislatures, so far as such functions had previously been exercised, and handed over to the courts. But obviously the power to deal with offenses of the latter class, being inherent, remained with the legislatures. The assembly cannot inflict punishment as punishment but only for the purpose of removing the obstruction to its proceedings and of preventing an immediate recurrence thereof. ${ }^{10}$

'See "Power of Congress oz'er Procedure in Criminal Contempts in 'Inferior' Fedcral Courts-A Siudy in Separation of Powers," by Felix Frankfurter and James M. Landis, 37 HARv. L. Rev. 1010-1012 (1923).

'Coffin v. Coffin, 4 Mass. I, 34-35 (1808).

- In re Chapman, 166 U. S. 66I, 671-2 (1896).

${ }^{10}$ Marshall v. Gordon, 243 . U. S. 521, 542-545 (1917). 
What has just been said of the effect of the separation of powers in this country applies, with some modifications, to the situation in England, in so far as the House of Commons is concerned. We are accustomed to think of the supremacy of Parliament and to fancy that the doctrine of separation of powers is not there exemplified. And indeed it is not in many particulars, for the legislative and the executive powers are largely blended in the cabinet, and legislative and judicial powers are combined in the House of Lords. ${ }^{11}$ But there is no more blending of the legislative and judicial powers in the House of Commons than is to be found in an American legislative body. As a result we find that the Commons have no substantive power to punish for crime. Its contempt powers are wholly ancillary. It can punish for the purpose of removing obstructions, but not for the purpose of enforcing the criminal law. ${ }^{12}$ It cannot assess fines, ${ }^{13}$ nor, for contempt of its authority, imprison for a term

2 The blending of these powers of government in the House of Lords is more nominal than real, for every lawyer knows that the House of Lords when sitting as a court is a very different body from the House of Lords sitting as a branch of the legislature. In fact, the great majority of the lords, the lay lords, have not attended and voted when cases were being heard on appeal since Daniel O'Connell's Case in 1844 . Their proposed participation in that case was quite unexpected and created something of a sensation, but Lord Iyndhurst was able to dissuade them. It is now forbidden by statute. See Atlay, Victorian Chancellors I, 144-145.

13 "A competence to commit for all matters and in all cases has never been asserted or pretended to on the part of either House of Parliament: the House of Commons does not pretend to a general criminal jurisdiction."-Lord Ellenborough, Chief Justice, in Burdett v. Abbott, supro, note 2.

"Some fines were assessed by the House of Commons in the seventeenth century, the last in 1666 . In this connection, the following extract from the debate in the Samuel Houston case in Congress, in 1832, will be found interesting:

"In April of last year, a debate arose in the House of Lords, upon the power of that body to fine and imprison, by way of punishment for a libel. "The Lord Chancellor expressed his opinion, as an individual peer, that though the House of Lords had the undoubted right of imprisonment, as the House of Commons had, in order to remove an obstruction to their proceedings, yet that he agreed with many great legal and constitutional authorities, that their right to imprison for a time certain, and to fix a fine certain, was a disputable question.' He said, 'The House of Commons has the power of commitment, but not for any time certain; they have the power to commit as a means of removing an obstruction.'

"The Chief Justice of the King's Bench had, at first, expressed a different opinion, but which, in the course of the discussion, he abandoned. In reply to what had fallen from the Chief Justice, the Chancellor said, 'IVhat were those reasons? I heard them, my lords, with wonder and 
extending beyond the existing session. Said Lord Denman, Chief Justice:

"However flagrant the contempt, the House of Commons can only commit till the close of the existing session. Their privilege to commit is not better known than this limitation of it. Though the party should deserve the severest penalties, yet, his offense being committed the day before a prorogation, if the House ordered his imprisonment but for a week, every court in Westminster Hall and every judge of all the courts would be bound to discharge him by habeas corpus." 14

\section{Judictal Review in ENGLAND}

As there is no written constitution in England liniting the subjects upon which Parliament can act, it can hardly be said that judicial review as it is exercised in this country exists there, except with reference to cases coming up from the colonies. So it may be stated with substantial accuracy that each house of the imperial Parliament defines its own privileges, determines when they have been violated, and, within certain limits, what punishment shall be inflicted. With the exercise of these powers the courts will not directly interfere. So while the writ of habeas corpus is always available to a person imprisoned by either house, the courts uniformly remand the prisoner to custody if the return shows that he is held on order of the house. The ground of the commitment will not be inquired into, and it is held that the re-

amazement. He tells you that, because the courts of law of Westminster Hall have the power to fine and imprison, so also must the House of Lords and Commons have that power. Good Godl my lords, who ever heard till this moment; when were you ever told till this day, when you have been told it by a Lord Chief Justice of England, that the House of Commons has the right to inflict fines and imprisonment upon his $\mathrm{Ma}$ jesty's subjects, in vindication of their privileges. No one, who knows any thing about the law and the constitution of the country, can hesitate for a moment in saying that the Lord Chief Justice is grievously in error here." "- Extract from speech of Samucl Beardsley, of New York, Cong. Debates, Vol. 8, Part 3, p. 2923.

"Stockdale v. Hansard, 9 Ad. \& El. I, II4 (1838). The statement by Chief Justice White in Marshall v. Gordon, supra, note Io, apparently at variance with Lord Denman's opinion, is of doubtful accuracy, even when applied to the period prior to the adoption of the United States Constitution, as he probably intended it to apply. 
turn need not state in what the contempt of the house consisted. ${ }^{15}$ It is the law and custom of Parliament, and not any restriction created or applied by the courts, that prevent the house from assessing fines and from imprisoning in contempt cases for a time certain.

While the courts will not directly interfere by habcas corpus to release a person held in custody by order of the House of Commons, they have on several occasions been brought into conflict with the House by being called upon indirctly to determine the validity of such restraint. The details of these controversies cannot be given here. It will be sufficient to say in the last of these struggles, extending over a period of ten years and involving the right of the House of Commons to protect its printer in publishing in obedience to its order parliamentary committee reports containing libellous matter, it was definitely decided that the courts will not discharge on habias corpus a sheriff held by order of the House even when his supposed contempt consisted in paying over money on the court's order. It was also decided that the Speaker's warrant is a complete protection for those who act in obedience to its mandate. ${ }^{18}$

Before passing from this subject a word should be said as to the contempt powers of the English colonial legislatures. The colonies have their written constitutions in the form of parliamentary grants of governmental powers, and so we find the courts passing on the question of "ultra vires," as the courts in this country pass on the question of the constitutionality of statutes. By the British North America Act, the "privileges, immunities and powers" of the Senate and the House of Commons of the

${ }^{13}$ The Earl of Shaftsbury's case, I Modern 144, 6 State Tr. 1269 (1677); Rex v. Flower, 8 T. R. 3I4 (I799) (said the court: "We were bound to grant this habeas corpus; but having seen the return to it, we are bound to remand the defendant to prison, because the subject belongs e.x aliud cxamein."); Rex v. Hobhouse, 3 B. \& Ald. 420 (1820); Case of Sheriff of Middlesex, II Ad. \& El. 273 (1840); MAY, 73-80.

${ }^{20}$ For an account of the earlier controversies see MAY, LAw, Privineges, Proceedixgs axd Usage of Parliament, I41-143.

For the later struggle, see Stockdale v. Hansard, 9 Ad. \& El. I-243 (1839); Id. II Ad. \& El. 253 (1840); Sheriff of Míiddlesex, I1 Ad. \& El. 273 (1840); Howard v. Gossett, 1o Q. B. 359 (1845); Gossett v. Howard, 1o Q. B. 411 (1847). Also see MAY, 143 et seq. 
Canadian Parliament and their members are to be determined by act of the Parliament itself, provided that they shall not exceed the privileges, immunities and powers contemporaneously enjoyed by the English House of Commons and its members. ${ }^{17}$ However, the statutes for the government of the other colonies are silent on the subject and the power of the provincial assemblies to punish for contempt has several times come before the Judicial Committee of the Privy Council. While it is held that these bodies have the contempt power, the later cases have limited its exercise, holding that these assemblies are purely local legislatures and do not possess the contempt power to the same extent as the House of Commons. ${ }^{18}$

The Kivlley ${ }^{19}$ case was relied upon to support some of the adverse dicta found in Kilbourn $v$. Thompson,,$^{20}$ but the correct$126 \mathrm{n}$.

"27 Ecrton, Federations and Unions Withix the British EMpire,

"The leading colonial cases are as follows:

Beaumont v. Burrett, I Mloody P. C. 59 (Eng., 1836), upholding the right of the Jamaica assembly to punish a newspaperman for libel.

Kielley v. Carson, 4 Moody P. C. 63 (Eng., 1842), a case zoming up from Newfoundland, in which the Beaumont case was criticised, and it was held that the Speaker and members were liable in damages for imprisoning the plaintiff for using violent and threatening language toward a member for words spoken in debate and for repeating the performance when called before the assembly to explain. This holding, however, was placed on the ground that the offence for which he was called before the house was already completed and such implied power as the assembly had existed for removing existing obstructions, not for punishing past offences, clearly an incorrect holding as depriving an assembly of the right to protect itself against immediate and repeated repetitions of insults and assaults. See Chief Justice White's criticism of this case in Marshall v. Gordon, supro, note 10, pp. 538-41, 544.

Feitton v. Hampton, is Moody P. C. 347 (Eng., 1857), from Van Dieman's Land, where a plaintiff was allowed to recover against the Speaker and sergeant for imprisoning on an order of the assembly for refusing to appear as a witness.

Doyle v. Falconer, L. R., I P. C. 328 (Eng., 1866), where a member who was committed for refusing to stop talking was allowed to recover against the Speaker and other members, it being held that the assembly could remove but not imprison him.

Ex parte Dansereau, I9 Lower Can. Jurist, 210 (1875), in which the Qucen's Bench of Lower Canada refused to discharge relator who was held by the Quebec assembly for refusing to appear as a witness at an inquiry concerning a government bond trade. A constitutional statute authorized the committment.

Ex parte Brozen, 5 B. \& S. 280 (Q. B., Eng., 1864), discharging a printer who had been committed for libel by the lower branch of the Manx legislature.

"Supra, note 18.

${ }_{103}$ U. S. 168 , 186-189 (1880). 
ness of the restriction of the contempt power stated in the Kielley case is .questioned and its inapplicability to American state and national legislative bodies is clearly shown by Chief Justice White in the recent case of Marshall $v$. Gordon."2 He shows that in spite of this restriction the case upholds the contempt power, stating his conclusion in the following language:

"There can be no doubt that the ruling in the case just stated upheld the existence of the implied power to punish for contempt as distinct from legislative authority and yet flowing from it. It thus becomes apparent that from a doctrinal point of view the English rule concerning legislative bodies generally came to be in exact accord with that which was recognized in Anderson $v$. Dunn, supra, as belonging to Congress, that is, that in virtue of the grant of legislative authority there would be a power implied to deal with contempt in so far as that authority was necessary to preserve and carry out the legislative authority given."

\section{Judicial Review in the United States}

The extent of judicial review in this country is on paper very different from that in England. While there the courts never interfere directly by habeas corpus and the speaker's warrant of commitment is a good defense in a civil action against those who act under it, in this country, the courts claim the right to determine whether the proceedings are in conformity with the constitution and the laws. ${ }^{22}$ But the main question that is re-

Supra, note I0, pp. 538-4I, 544

- Thus, in Burnham v. Mforrissey, 14 Gray 226, 238 (Mass., 1859), the court says:

"The house of representatives is not the final judge of its own powers and privileges in cases in which the rights and liberties of the subject are concerned, but the legality of its action may be examined and determined by this court. That house is not the legislature, but only a part of it, and is therefore subject in its action to the laws, in common with all other bodies, officers, and tribunals within the Commonwealth. Especially is it competent and proper for this court to consider whether its proceedings are in conformity with the Constitution and laws, because, living under 2 written constitution, no branch or department of the government is supreme; and it is the province and duty of the judicial department to determine in cases regularly brought before them, whether the powers of any branch of the government, and even those of the legislature in the enactment of laws, have been exercised in conformity to the Constitution; and if they have not, to treat their acts as null and void." 
viewed by our courts is whether or not the business upon which the assembly was engaged was within its jurisdiction. If, for example, the House of Representatives is engaged in investigating a subject over which it has no jurisdiction of any kind, the courts will discharge on habcas corpus a witness who is committed for refusal to testify. This was illustrated in the case of Kilbourn $v$. Thompson, ${ }^{23}$ which will be discussed in another place. And in such a case the officer imprisoning is not protected by the speaker's warrant of commitment. On the other hand, if it be granted that the House had jurisdiction of the subject-matter, then our courts, like the English courts, usually go no further.

It will be observed that in the extracts heretofore given from the courts and commentators, ${ }^{24}$ no distinction is made between the different functions that a legislative body may be called on to perform. . All alike are protected by the contempt powers inherent in such bodies. It would seem to follow, therefore, that the distinction that has been attempted in some cases between the right to punish when the legislative body is acting in its socalled judicial capacity as distinguished from its legislative capacity, is essentially unsound. Logically the power is equally available when the legislature is seeking information which it deems necessary for framing legislation and when it is carrying. on an investigation to determine an election contest, or to impeach a public official. It follows that the question as to the power of legislative assemblies to punish resolves itself largely into an inquiry as to the legitimate functions of legislative bodies. The cases in this country will, therefore, be considered in five groups, dealing with the functions of legislative bodies.

I. The protective or defensive function, that is, the power of an assembly to punish those who disturb its. order and decorum, or assault its members, or otherwise physically obstruct its proceedings.

2. The defensive power against slander and libel of the assembly or of its members. Logically these cases belong in the

Supra, note 20.

25ee pp. 780-1-2, supra. 
preceding group, but they are here treated separately because the Supreme Court has dealt with them differently.

3. The judicial function, as in the determination of election cases and impeachment charges.

4. The legislative function, where the assembly is seeking information deemed necessary for enacting laws or voting supplies.

5. The informing or educative function, where the principal purpose is to educate the voters, or to bring to bear on administrative problems the force of enlightened public opinion.

\section{A. Protcctive or Defensive Function}

From early colonial days American legislative bodies have dealt promptly and vigorously with persons who sought to disturb or obstruct their proceedings or to bribe or assault their members. In fact no instance has been found where an assembly, either state or national, has in a clear case, refused to exercise its defensive powers solcly because of a supposed want of authority to defend itself. On the contrary attempts to bribe were effectively dealt with by Congress in the Randall and Anderson cases; the right of members to be free from assaults was vindicated in the Cole and Houston cases; and in the Lane case arrest of an officer of the house for confining a disturbing spectator was resented as a high breach of privilege. ${ }^{23}$

The power thus asserted by the houses of Congress has not been questioned by the courts either state or national. The lead-

\footnotetext{
${ }^{23}$ Other instances of punishment by Congress for similar offenses are as follows :

A. P. Field ( 1865$)$, for attempted intimidation and assault upon a member. 2 Hinds, Ion7.

Patrick Woods, (1870), assault on member absent on leave, but returning to the House. In this case the House committed for a period beyond adjournment of the session, holding that the expiration of the term of the members on March 4, 1871, fixed the limit of confinement. This was of very doubtful validity. See quotation from Chief Justice Denman, page 785. The house ordered him taken to Richmond, Va., in custody of the sergeant-at-arms, to testify in court. 2 HrNDS, 1097-1101.

Benjamin F. Bezeridge (1866), assault on clerk of a committce of the House, 2 HINDS, I IOI-2.

Henry G. Wheeler, newspaper correspondent (I886), assault on another newspaper correspondent on the floor of the House while the House was in session. 2 Hinds, 1102-3.
} 
ing case on the subject is Andirson $v . D u m n,{ }^{28}$ previously referred to in another connection. It will be recalled that Anderson was imprisoned by order of the House of Representatives for attempting to bribe a member. After being discharged from custody he sued Dunn, the Sergeant-at-Arms, for assault and battery and false imprisonment. The court in a unanimous opinion held that the action did not lie, saying, as previously quoted in this paper, that the proposition that "such an assembly should not possess the power to suppress rudeness, or repel insult, is a supposition too wild to be suggested." Continuing, the court, in a unanimous opinion written by Mr. Justice Johnson, said:

"But it is argued that the inference, if any, arising under the constitution, is against the exercise of the power here asserted by the louse of representatives; that the express grant of power to punish their members respectively, and to expel them, by the application of a familiar maxim, raises an implication against the power to punish any other than their own members.

"This argument proves too much; for its direct application would lead to the annihilation of almost every power of congress. To enforce its laws upon any subject without the sanction of punishment is obviously impossible. Yet there is an express grant of power to punish in one class of cases, and one only; and all the punishing power exercised by congress in any cases, except those which relate to piracy and offenses against the laws of nations, is derived from implication. Nor did the idea ever occur to any one, that the express grant in one class of cases repelled the assumption of the punishing power in any other." 27

In the same connection the Supreme Court gave what it regarded as the reason why the framers of the Constitution deemed it desirable expressly to authorize the houses to punish and expel their own members, while at the same time they left the power to punish non-members to be derived by implication from the nature of legislative bodies. The court said:

- Supra, note 3.

r7 6 Wheat. 232-3. Similar effect was given to the provision of the constitution of Massachusetts in the case of Burnham v. Morrissey. I4 Gray 226, 239. 
"The truth is, that the exercise of the powers given over their own members, was of such a delicate nature, that a constitutional provision became necessary to assert or communicate it. Constituted, as that body is, of delegates of confederated States, some such provision was necessary to guard against their mutual jealousy, since every proceeding against a representative would directly affect the honor or interests of the State which sent him." 28

This is the great classic case in America, on this subject, and although some of the dicta in it have been sought to be limited, as in the Kilbourn case, ${ }^{29}$ its fundamental principles have never been questioned by later state or national decisions.

The same result was reached by the supreme court of Texas in the case of Canfield $v$. Gresham. ${ }^{30}$ In that case, plaintiff, a newspaper reporter, was held to be in contempt of the House and was imprisoned by its order for causing the arrest of the speaker and the sergeant-at-arms. After his release he brought an action against the speaker, the sergeant-at-arms, and the members that voted for the resolution of commitment. An instructed verdict for the defendants in the court below was affirmed in a brief opinion, the court regarding plaintiff's conduct as an obstruction of the proceedings of the house. ${ }^{31}$

In a number of cases the contempi power has been called into use to enable legislative assemblies to investigate charges of bribery or corruption on the part of their own members. Such investigations may have one or more purposes in view, such as the punishment or expulsion of the members if found guilty, or the punishment of the bribe givers, or the vindication of the good

26 Wheat. 233. This argument would apply with especial force to the Senate, whose members in the early years were looked upon as quasi-ambassadors representing the states as organized governments.

- Supra, note 20 .

${ }^{\infty} 82$ Tex. 10, 17 S. W. 390 (1891).

" The force of this decision is somewhat weakened by the fact that there was a constitutional provision stating that "each house may punish by imprisonment, during its session, any person not a member... for obstructing any of its proceedings, provided such imprisonment shall not at any time exceed forty-eight hours." - Const. of Texas, Art. 8, Sec. 15. But, as is elsewhere shown in this paper, such a provision serves to define and linit the contempt power rather than to create or confer it. 
name of the body, or the punishment of the persons making the charges if the charges are found to be a slanderous libel. The purpose might also be to strengthen the criminal laws applicable to such offenses. Usually the resolutions under which such investigations are made fail to indicate which of these motives is the main-spring of the action, but such failure is generally held not to affect the right of the body to proceed. Thus, in the case of Sullivan v. Hill, ${ }^{32}$ the court held it immaterial that the resolution creating a committec to investigate charges of bribery did not state what use was expected to be made of the information to be obtained. Said the court:

"That subject at once suggests, expulsion of its members, if found to be bribe takers, and further legislation on the subject of punishing the crime, clearly within the powers of the legislature enumerated in the Constitution." 33

A similar result was reached in the case of $E_{x}$ Partc McCarthy, ${ }^{34}$ where the court in an excellent opinion refused to discharge relator from the custody of the state senate by which he had been imprisoned for refusing to testify in an investigation of bribery charges. There were certain constitutional and statutory provisions authorizing the punishment, but the court rested the case on the inherent power of legislative assemblies, saying that

"These powers of the Senate, under the common parliamentary law, are not trenched upon by the Constitution or any law made in pursuance thereof. On the contrary,

${ }^{23} 73$ W. Va. 49, 79 S. E. 670 (1913).

${ }^{23} 73 \mathrm{~W}$. $\mathrm{Va}$. 54 One feature of this case deserves mention. It was a case of punishment ordered by the committee, not by either house of the legislature, a statute of the state authorizing such action by the committee. Code of 1906 , Sec. $7, \mathrm{Ch}$. 12. The general rule is that in the absence of statute a committee cannot punish for contempt, but must report back to the house and the latter orders the imprisonment.

A similar statute, authorizing punishment by a committee, was recently held unconstitutional by the Court of Criminal Appeals of Texas, as being in conflict with the provision of the constitution of that state quoted above. Ex parte Youngblood, 251 S. IV. 509 (1923).

"Supra, note 4. This case is followed in Ex parte Lawrence, II6 Cal. 268, ${ }_{4} 8 \mathrm{Pac}$. 124 (1897), also involving newspaper charges of bribery on the part of members. 
so far as the Constitution and laws of the State treat of the subject, they but affirm and enlarge, so far as the present case is concerned, the common parliamentary law."

In an early case in Wisconsin, ${ }^{35}$ the court upheld the right of one legislature to investigate charges of bribery and corruption on the part of members of a preceding legislature, in relation to the disposition of lands granted to the state by Congress in aid of railroad construction. The resolution authorizing the investigation did not state the use to be made of the information, but the court found no difficulty in suggesting possible uses to which the information might be put, saying that the inquiry "might show the necessity of some further legislation in regard to these grants, some more stringent regulation of the company to secure the application of them to the early and speedy completion of the roads, or perhaps some amendments of the Charters, to prevent further mischief." 38

The most notable case involving the right of an assembly to investigate charges of corruption on the part of its members and to punish contumacious witnesses in connection therewith, is the case In re Chapman. ${ }^{37}$ During the passage of the tariff act of I894, charges were made in the newspapers that members of the Senate were yielding to corrupt influences, and were speculating on the New York Stock Exchange in the stock of certain sugar refining companies, while the sugar schedule was under discussion. As a result the Senate appointed a committee to investigate the charges, and Chapman, a member of a New York brokerage house, refused to give information called for by the committee. He was prosecuted criminally in the courts of the District of Columbia and sentenced to serve a jail term, under certain articles of the revised statutes, derived from an act passed by Congress, in 1857 , "to enforce the attendance of witnesses on

"In re Falvey, 7 Wis. 630 ( 1858 ).

${ }_{7}$ Wis. 636,637 . In this case, as in some of the others here discussed, there were constitutional and statutory provisions authorizing the punishment of contumacious witnesses, but the court asserts that the power is inherent in legislatize bodics. See pp. 638-639.

"Supra, note 9 . 
the summons of either House of Congress, and to compel them to discover testimony." 38 He sought to be discharged on habeas corpus, setting up, among other things, that the Senate had no right to carry on the investigation, and hence no authority to sumnon him, and therefore his refusal to testify was not within the terms of the statute. But the court in an able opinion by Chief Justice Fuller brushed aside this contention, saying:

"According to the preamble and resolutions, the integrity and purity of members of the Senate had been questioned in a manner calculated to destroy public confidence in the body, and in such respects as might subject members to censure or expulsion. The Senate, by the action taken, signifying its judgment that it was called upon to vindicate itself from aspersion and to deal with such of its members as night have been guilty of misbehavior and brought reproach upon it, obviously had jurisdiction of the subjectmatter of the inquiry it directed, and power to compel the attendance of witnesses, and to require them to answer any question pertinent thereto." 38

It will be noted that the court here recognized the right of the Senate "to vindicate itself from aspersion," along with the right to expel corrupt members, as a sufficient ground for ordering the investigation. The fact that the resolution of the Senate ordering the investigation did not indicate the purpose which the Senate had in view was treated as a matter of no significance. $^{10}$

\section{B. Libcl and Slander}

There seems to be one exception to the rule that the courts will sustain a legislative body in the exercise of its defensive powers, in repelling assaults, insults, and attempts to bribe its

${ }^{28}$ II Stat. 155, c. 19, brought forward as Sections 102, 103, 104, and 859, of the Revised Statutes.

166 U. S. 668.

166 U. S. 669-670. For an early case upholding the Senate's right to protect its rules of secrecy and to punish a newspaper correspondent who refused to tell how he procured for publication a copy of the Treaty of Guadalupe Hidalgo, with Mfexico, while it was being considered in executive session, see Ex parte Nugent, Fed. Case No. 10,375 (C..C., 1848). 
members-if an exception may be deduced from a single decision. That exception is that a legislative assembly cannot treat a printed libel of the assembly or of its committees as a contempt and punish it as such. The case is Marshall $v$. Gordon, ${ }^{41}$ decided by the Supreme Court of the United States, in 1917. It came up on appeal from a decision of the Federal District Court for the Southern District of New lork remanding relator, H. Snowden Marshall, district attorney for the said district, to the custody of the sergeant-at-arms of the House of Representatives of the United States Congress. The judgment was reversed and the relator ordered discharged.

In order to understand the full significance of the case it will be necessary to state the facts in some detail. In December, 1915, the Federal grand jury, under the direction of District Attorney Marslıall, was engaged in an investigation of alleged violations of the Sherman Anti-Trust Law by a certain member of Congress and others, and of the asserted illegal activities of an organization known as "Labor's National Peace Council," to which the member belonged. While the investigation was going on and after notices of it had appeared in the Niew York papers, the member rose in his place in the House and solemnly "impeached" the district attorney of many acts of misfeasance and nonfeasance in office. A few days later the grand jury in New York returned an indictment against the member charging him with violation of the Anti-Trust Law. Two weeks later, the member again "impeached" the district attorney and moved that the judiciary committee be instructed to investigate the charges. This was adopted and the committee was authorized to appoint a subcommittee which should have power to send for persons and papers. The subcommittee was appointed. During the hearings in New York, friction arose between the subcommittee and the district attorney's office based upon the assertion that the committee was attempting rather to investigate and frustrate the action of the grand jury than to investigate the conduct of the district attorney. This charge was printed in a daily newspaper,

- Supra, note 10. 
and when the reporter was called before the subcommittee and was asked if the district attorney or any of his assistants had given him the information on which the charge was based, he refused to answer. Thereupon the district attorney wrote a letter to the chairnan of the subcommittee and at the same time gave it to the press, saying that he himself was the informant, asserting that the charges were true, and amplifying them in language "which was certainly unparliamentary and manifestly illtempered, and which was well calculated to arouse the indignation not only of the members of the subcommittee but of those of the House generally." 42

When the letter was reported to the House by the judiciary committee, a special committee was appointed to look into the matter. It called the district attorney before it and he there repeated the charges made in the letter, "averring that they were justified by the circumstances and stating that they would under the same conditions be made again." Thereupon the House, by a vote of 209 to 85, with 16 "present," and 124 not voting, ${ }^{43}$ adopted the resolution recommended by the special committee, declaring the letter, "as a whole and in several of the separate sentences, defamatory and insulting," and as tending "to bring the House into public contempt and ridicule," and that "H. Snowden Marshall, by writing and publishing the same, is guilty of

\footnotetext{
a Some of the expressions contained in this published statement are as follows:

"You are exploiting charges against me of oppressive conduct toward a member of your honorable body who is charged with a violation of law and of oppressive conduct on my part toward shysters in the blackmailing and bankruptcy business.

"I may be able to lighten your labors by offering to resign if you can indicate anything I ever did that remotely approximates the lawless tyranny of your order of arrest of Mr. Holme" [the reporter].

"I said that your expedition to this town was not an investigation in good faith, but was a deliberate effort to intimidate any district attorney who had the temerity to present charges against one of your honorable body."

"Your whole proceeding here was irregular and extraordinary."

"It is amazing to me to think that you supposed that I did not understand what you have been attempting to do during your visit here. I realized that your effort. was to ruin me and my office by publishing with your full approval the complaints of various persons who have run afoul of the criminal law under my administration." Cong. Rec., Vol. 53, Part 6, p. 6136 (Apr. 14, 1916).

${ }^{4}$ Cong. Rec., Vol. 53, Part 10, p. 9670.
} 
contempt of the House of Representatives of the United States because of the violation of its privileges, its honor and its dignity."

Upon the adoption of this report, a formal warrant was issued, Marshall was arrested, and, as stated above, was discharged on habeas corpus by the Supreme Court. In its opinion, which was written by the late Chief Justice White, the court does not question the power of the House, in a proper case, to punish for contempt. On the contrary, the opinion contains a very clear presentation of the difference between the adjective power of a legislative body to punish as a means of protecting itself and of removing obstructions to its proceedings, and the substantive power of the courts of inflicting punishment as such in vindication of the laws against crimes. It also distinguishes between the legislature's implied power to remove obstructions to its proceedings and its substantive power to declare acts criminal and provide for their punishment by the courts. In developing this last distinction the court said:

"The legislative history of the exertion of the implied power to deal with contempt by the Senate or House of Representatives when viewed comprehensively from the beginning points to the distinction upon which the power rests and sustains the limitations inhering in it which we have stated. The principal instances are mentioned in the margin and they all except two or three deal with either physical obstruction of the legislative body in the discharge of its duties, or physical assault upon its members for action taken or words spoken in the body, or obstruction of its officers in the performance of their official duties, or the prevention of members from attending so that their duties might 've performed, or finally with contumacy in refusing to obey orders to produce documents or give testimony which there was a right to compel. In the two or three instances not embraced in the classes we think it plainly appears that for the moment the distinction was overlooked which existed between the legislative power to make criminal every form of act which can constitute a contempt to be punished according to the orderly process of the law and the accessory implied power 
to deal with particular acts as contempts outside the ordinary process of the law because of the effect such particular acts may have in preventing the exercise of legislative authority." 14

Just what the "two or three instances" referred to by the Chief Justice were we are left to conjecture. IVe can with a fair degree of certainty assume that the Duane libel case, in 1800 , is one, since in the instant case the decision is that libel is not an offense that can be dealt with by the exercise of the contempt power. Perhaps the other two instances are the two bribery cases of 1795 and 1818 , for they do not seem to come within the classes mentioned. But, to include these bribery cases in the court's condemnation, would overthrow Anderson v. Dum, which is quoted in the opinion with no intimation that the result there reached is in any way disapproved. And yet it is very difficult to see how bribery can come within any one of the five classes any more than libel and slander come within them. Then, too, we may very well inquire whether it be really true that libel and slander are not obstructions to proper legislation quite as much as some forms of physical interference. If legislation were purely a physical process, then possibly physical restraint only could be regarded as an effectual obstruction. But it need not be said that legislation is not predominantly a physical operation and that the better the legislation the less does the physical predominate. The essentials of effective legislation are research, reflection, deliberation-qualities of mind that cannot flourish in an atmosphere of villification, slander and libel. It seems evident that anything that stirs the passions and arouses the righteous in-

4243 U. S. 543-544. [Italics mine.] The list of instances given by the court in the margin is as follows:

"1795, attempt to bribe members of the House; 1800 , publication of criticism of the Senate; 1809 , assault on a niember of the House; 1828, assault on Secretary to the President in the Capital; 1832, assault on a member of the House; 1835 , assault on a member of the House; 1842, contumacious witness; 1857 , contumacious witness; 1858 , conturnacious witness; 1859, contumacious witness; 1865 , assault on a member of the House; 1866 , assault on a clerk of a committee of the House; 1870, assault on a member of the House; 1871 , contumacious witness; 1874 , contumacious witness; 1876 , contumacious witness; 1894, contumacious witness; 1913, assault on a member of the House." 
dignation of legislators or of a deliberative body as a whole, is as truly an obstruction of its proceedings as any act coming within the classes enumerated in the opinion ${ }^{45}$

That the opinion is a very wide departure from the legislative history in this country and in England is apparent from the cases given in this paper, ${ }^{+6}$ and from the many cases collected by Sir Thomas Erskine Maj in his work on parliamentary practice. ${ }^{47}$ It is true that a great change has come about in the attitude of courts and legislatures with reference to the functions of the press. One hundred and sixty years ago it was a serious offense to publish, without permission, the debates or any part of the proceedings of Parliament or of our colonial assemblies. But the Alien and Sedition laws of our early history rendered very unpopular attempts to suppress newspaper criticism of public officials, and in recent years there has been a growing demand in favor of making criminal contempts, whether of courts or of legislative bodies, substantive crimes to be tried by ordinary courts and juries, as was done by Congress, in a limited class of cases, in the Clayton Act of I9I $4^{47^{4 a}}$ But with all due allowance for these changes in sentiment, it is hard to believe that no newspaper assaults, howerer false and scandalous, and however often

* The leading English case upholding the right of the House of Commons to imprison a person publishing a libel upon the House is Burdett v. Abbott, supra, note 2 . In that case the speaker was held not liable for assault and false imprisonment for issuing his warrant in obedience to the order of the House, under which the plaintiff's doors were broken vi et armis and he was imprisoned in the Tower. In the course of a very able opinion, reviewing the earlier cases, Lord Ellenborough made these pertinent inquiries:

"Is not the degradation and disparagement of the two Houses of Parliament in the estimation of the public, by contemptuous libels, as much an impediment to their efficient acting with regard to the public, as the actual obstruction of an individual member by bodily force, in his endeavor to resort to the place where Parliament is holden? And would it consist with the dignity of such bodies, or what is more, with the immediate and effectual exercise of their important functions, that they should wait the comparatively tardy result of a prosecution in the ordinary course of law, for the vindication of their privileges from wrong and insult?"

${ }^{4} 74$ U. OF PA. L. REv. GoI.

"MAY, 85-88, 89-93.

47 38 Stat. 738, 739, Secs. 21, 22; Michaelson v. United States, 266 U. S. 42 (1924); "Power of Congress Oz'er Procedure in Criminal Contempts in Inferior Federal Courts-.A Study in Separation of Powers," by Felix Frankfurter and J. M. Landis, 37 HARv. L. REv. roro-1113. 
repeated and long continued, can be properly regarded by a legislative assembly as a contempt and punished as such.

It seems probable that in the case of Marshall $v$. Gordon the court was strongly influenced by the very peculiar state of facts there involved. For one cannot close his eyes to the fact that there is much to give color to the district attorney's charges that a member of Congress was prostituting his great privilege of instituting impeachment charges against public officials for the purpose of saving himself. This is strongly intimated in some of the speeches in the House, ${ }^{48}$ and it so impressed the executive committee of the bar association of New York City, that it did the very unusual thing of adclressing a letter to the speaker of the House, which, after calling attention to the sequence of the events leading up to the investigation, says:

"What this association desires respectfully to submit to you and the House of Representatives is a consideration of the effect upon the administration of criminal justice of legislative proceedings undertaken at the instance of a Mem-

"For example, Congressman Graham of Pennsylvania said:

"The course that I would have pursued-and I say it with all respect to the gentleman from Illinois-is this: I would not have risen in my place and said, 'I impeach my prosecutor.' I would have said, 'Mr. Prosecutor, you are prosecuting an innocent man. I demand a trial by my peers in the usual course of the law of the land, and $I$ will stand and meet it.' And then, when that had transpired, if this prosecutor had shown malevolence or ill will, I would have adopted the other remedies."

A little later he said:

"When the proccedings were carried on in New York, two things transpired that I think were wrong. No doubt the subcommittee feit itself - justified in adopting the course of holding open meetings. No doubt they felt themselves justified in calling the grand jurors before them for examination, but I respectfully submit that in both they erred, for when the public hearing was had the Rae Tanzers and the other people who were witnesses came in on the stand and testified, and all this was published in the papers without Mr. Marshall having a chance to reply or say a word. It was stimulating indignation; it was calculated to create anger. Then when he saw how this subcommittee questioned grand jurors, although it was composed of lawyers-every man here knows what a grand juror's oath is when he swears that he will maintain secret and inviolate his own and his fellow's counsels and all that transpired in the grand jury room. Who clothed a committee of Congress with power to ask a man to violate his oath? Who clothed this subcommittee with power to penetrate the grand jury room and to make them reveal how and why they voted. . . If ever there was an invasion of the plainest principles of justice and correct procedure it occurred then." Cong. Rec., Vol. 53, Part Io, pp. 9643-4. 
ber of Congress indicted, or about to be indicted, in investigating the United States Attorney under whose direction the indictment has been or is being prosecuted, before the trial of the Member who has been indicted, and in reference to the very subject-matter of the indictment." 49

Such considerations must have had a very powerful influence on the judicial mind and helped to bring about a decision that might not have been reached if the same libellous statement had been published under an entirely different state of facts. At any rate, until other cases are decided in line with the Marshall case, the present writer is unwilling to accept, as a settled rule of law, that a legislative assembly cannot under any circumstances protect itself against maliciously false and scandalous publications calculated to disturb its deliberations and subject it to public contempt and ridicule."o

\section{The Judicial Function}

It should be borne in mind that logically there is no distinction, so far as the right to exercise the contempt power is concerned, between the different functions that a legislature may be called upon to perform. But the courts have not always recognized this elemental fact, and we find them inclined, in impeachment cases and cases involving the election and qualification of their members, to say that the assembly is here acting in a "judicial capacity" and that it should therefore be allowed the same freedom in the use of its contempt powers as is enjoyed by a court. In Kilbourn v. Thompson, hereafter to be considered in detail, the court said:

* This very. interesting document, signed by former Attorney General George W. Wickersham, as president of the association, is printed in full in the Congressional Record. Cong. Rec., Vol. 53, Part 1o, pp. 9645-6.

${ }^{\infty} \mathrm{It}$ is of interest to note that Senator Charles Sumner, of Massachusetts, who strenuously denied the right of the Senate to punish Hyatt, a contumacious witness in an investigation carried on in aid of law making, reluctantly admitted that the Senate was right in the Duane case, on "that principle of universal jurisprudence, and also of natural law, which gives to everybody, whether natural or artificial, the right to protect its own existence; in other words, the great right of self-defense." Cong. Globe, 36 th Leg. Ist Sess., part 4, p. 3007.3 Hinds, Precedexts, 77. 
"The House of Representatives has the sole right to impeach officers of the government, and the Senate to try them. Where the question of such impeachment is before either body acting in its appropriate sphere on that subject, we see no reason to doubt the right to compel the attendance of witnesses, and their answer to proper questions in the same manner and by the use of the same means that courts of justice can in like cases."

This attiude of the judicial mind is observable in the cases already considered, involving charges of bribery and corruption on the part of members, for since such investigations may lead to the trial and expulsion of members found to be corrupt, they may be regarded as necessary first steps in the exercise of the "judicial function." 52

In view of this attitude of the courts it would be a waste of time to discuss many cases under this head, even if they were at hand, but they are not to be found in profusion, possibly for the reason that defendants and their counsel have not thought it worth while to carry such cases to the higher courts. However, a very good case in point is Ex parte Dalton. ${ }^{53}$ In that case relator refused to produce certain poll-books and tally-sheets before a committee of the house of representatives engaged in trying a contested election case. He was committed for contempt of the house, and on habeas corpus the state Supreme Court remanded him to custody, saying:

"That the power to commit a recusant witness for contempt in disobeying the command of a subpœna issued in

"103 U. S. 168, 190. The same view is expressed by Justice Learned, in McDonald v. Keeler, 39 Hun. 563 (N. Y., 1886), where, in speaking of the power to try contested election cases and the power to present. and try impeachments, the court said:

"These are judicial powers. They imply a decision on past occurrences, and a giving judgment accordingly. It may be, therefore, that in all actions of this kind, the senate and assembly may rightfully enforce the same power of punishing for refusing to answer questions which is exercised by courts."

" See the cases of Sullivan v. Hill, Ex parte McCarthy, In re Falvey, In re Chapman, and Ex parte Nugent, fp. 793-4-5, supra.

44 Ohio 142 (1886). 
the due course of an investigation affecting the election of any of its members, is invested in each house, is now too firmly established to be considered a debatable question." 34

\section{The Law-Making Function}

If the position of the cuurts and commentators is sound that the contempt power is inherent in legislative bodies and may be used as an aid in the performance of their legitimate functions, there is left no room to doubt that it may be used in aid of lawmaking, which is usually thought of as the most essential and characteristic function of such bodies. And yet we find that doubt on this point was raised by some of the language used in Kilbourn $v$. Thompson, though the point was expressly reserved for. future decision. ${ }^{55}$ The question has never been directly decided by the Supreme Court of the United States, but a review of the cases decided by the state courts and of the practice of the two houses of Congress will show beyond a doubt that the contempt power may properly be exercised to obtain information as a basis for intelligent law-making. And first, as to the state decisions.

One of the earliest cases on this subject is Burnham v. Morrissey. ${ }^{.6}$ In that case a special committee was appointed to investigate the state liquor agency. It does not appear whether the purpose was to obtain information for legislation, or to bring about the removal of Burnham, the commissioner in charge. Being present during the hearing, Burnham was called on to

"Id., I52-153. There was a statute authorizing such action by the house, but the court rests the case on the authority of Anderson v. Dunn, and Kilbourn v. Thompson. For another election contest case see In re Gunn, 50 Kan. İ5, 2II, 32 Pac. 470 (1893).

${ }^{35} 103$ U. S. 168 . At page 189 , the court says:

"Nor, taking what has fallen from the English judges, and especially the later cases on which we have just commented, is much aid given to the doctrine, that this power exists as one necessary to enable either House of Congress to exercise successfully their function of legislation.

"This latter proposition is one which we do not propose to decide in the present case, because acc are able to decide it without passing upon the existence or non-existence of such a power in aid of the legislative function." [Italics mine.]

- Supra, note 22. 
produce certain books in which his liquor accounts were kept. He refused and was committed for contempt, and on habeas corpus was remanded to custody. The court after asserting its right to review the action of the house and explaining that the clauses of the constitution authorizing the houses to punish offenders in certain cases did not work a denial of the power in other cases not mentioned, 5 held that the house had full authority to compel witnesses to furnish information "in order to the proper performance of legislative duties." 58

A later and perhaps a stronger case is that of $M I c$ Donald $v$. Kcelcr. ${ }^{59}$ The state Senate appointed a special committee to investigate newspaper charges of fraud against the commissioner of public works of the city of New York, with instructions to report the results of its investigation, "and its recommendations concerning the same." McDonald was summoned before the committer but refused to answer certain questions and was committed fur contempt. The court refused to discharge him on habcas corpus. The right of the senate to punish was upheld under the statute of 1830 , but the court held that the purpose and effect of that statute was to define and restrict the contempt powers that are inherent in all legislative assemblies, saying that "it was deemed proper to provide a legislative definition of those privileges of the houses and their members, the breach of which should be regarded as a contempt," and that it was not intended by the revisers in retaining the statute in the revised laws "to deprive the two houses of the powers which the revisers characterize as indispensable, of punishing contempts."

Although the resolutions under which the committee was appointed did not state what use was to be made of the information gained, the court interpreted the instruction to the committee to report its "recommendations" as implying that legislation of some sort was in contemplation. The court said:

"The power of obtaining information for the purpose of framing laws to meet supposed or apprehended evils, is

"See footnotes 22 and 27 , supra, pp. 788-791.

" 14 Gray 239 (Mass., 1859).

99 N. Y. 463,2 N. E. 615 (1885). 
one which has from time immemorial been dcemed necessary and has been exercised by legislative bodies. In this State it does not rest upon precedent merely, but is expressly conferred by statute. . .

"It is difficult to conceive any constitutional objection which can be raised to the provisions authorizing legislative committees to take testimony and to summon witnesses. In many cases it may be indispensable to intelligent and effectual legislation to ascertain the facts which are claimed to give rise to the necessity for such legislation, and the remedy required." 60

The courts in a number of other states have upheld the right of legislative bodies to punish contumacious witnesses where the investigation that was being carried on was, in whole or in part, for purely law making purposes. Ex parte Parker ${ }^{61}$ was like Burnham $\approx$. Morrissey, ${ }^{62}$ in that the state liquor dispensary was under investigation under a resolution that did not indicate the purpose for which the information was to be used. The relator was remanded to custody, the court saying:

"The power of the general assembly to obtain information on any subject upon which it has power to legislate, with a view to its enlightenment and guidance, is so obviously essential to the performance of legislative functions that it has always been exercised without question." 63

A very good recent case on the power of a legislative body to carry on an investigation for law-making purposes is State $v$.

${ }^{\infty}$ From this position the New York courts have never receded, though there have been cases, in which the action of the legislative body was not sustained. (Sce pp. 816-817, infra.) Other New York cases in accord, some decided before and some after that case, are the following: Briggs v. MrKellar, 2 Abb. Prac. 30 (1855); Wickelhausen v. Willett, to Abb. Prac. 164 (1860), affirmed as Wilckens v. Willett, I2 Abb. Prac. 319 (1864); People v. Sharp, 107 N. Y. 427,14 N. E. 319 (1887).

${ }^{17} 74$ S. C. 466,55 S. E. 122 (1906).

- Supra, note 22

- The legislature had passed a special statute after this investigation was under way, to remove all possible doubt of the power to punish contumacious witnesses, but the court sustains the commitment on the broad grounds laid down in Anderson v. Dunn, In re Chapman, Burnham v. Morrissey, McDonald v. Keeler, People v. Sharp, and Matter of Gunn, all of which are cited with approval. 
Frcar. ${ }^{04}$ This was a petition to commence an action to restrain the Secretary of State and the State Treasurer from using any public funds to pay the expenses incurred by a legislative committee appointed to investigate the workings of the primary election law governing the selection of candidates for the United States Senate. The petition was denied, the court saying:

"The legislature has very broad discretionary power to investigate any subject respecting which it may desire information in aid of the proper discharge of its function to make or unmake written laws, or perform any other act delegated to it by the fundanental law, state or national, and to proceed, with that end in view, by a duly authorized committee of one or buth branches of the legislature to incur reasonably necessary expenses, payable out of the public funds."

Other state cases upholding the exercise of the contempt power as an aid to law-making are referred to in the margin. ${ }^{65}$

138 Wis. 173,119 N. W. 894 (1909).

- In re Dazis, 58 Kan. 368, 49 Pac. 160 (1897).

"That legislative bodics have the power to enforce obedicnce to their rules of order and to compcl witnesses to give testimony upon matters calling for legislative action, though sometimes questioned, is well established, and should be regarded as the settled law."

Lowe v. Summers, 69 MI. App. 637 (1897). (Investigation of metropolitan police and election systems, to the end that they may be "corrected by adequate legislation.")

The cases In re Falz'y", 7 Wis. 630 (1858); Ex parte McCarthy, 29 Cal. 395 (1866); and Sullivan v. Hill, 73 W. Va. 49, 79 S. E. 670 (1913), previously discussed and quoted from, pp. 793-4-5, sustained the commitments in part on the ground that the information was sought as an aid to lawmaking.

Two interesting cases arose in Texas, in IgII, in which the Court of Criminal Appeals assumed, without deciding, that either house of the legislature could commit for contempt where a witness refused to give testimony in a hearing in aid of legislation. In those cases, Ex parte Wolters, $64 \mathrm{Tex}$. Crim. Rep. 238, 144 S. W. 531 ; and Ex parte Gray. 64 Tex. Crim. Rep. 311, I44 S. W. 531, the court discharged from custody Wolters, committed by the house, and Gray, committed by the senate, for their refusal to testify before committees of the respective houses, appointed to investigate alleged improper use of funds in a prohibition election. The legislature had been called in special session by proclamation of the governor for the purpose of passing the general appropriation bills and for other purposes named in the call. The election frauds were not mentioned by him. Presiding Judge Davidson held that the houses had no jurisdiction to investigate any subject of legislation that was not mentioned in the call; hence he favored discharging the relators. Associate Judge Harper held that the houses had a right to investigate the election frauds, for (I) the information would be of use in future legislation, as in the case of information gathered by committees appointed to sit during adjournment, and 
As previously stated, the legality of the use of the contempt power for purely law-making purposes has not been passed upon by the United States Supreme Court. In such a case, the courts give great weight to legislative practice, as indicating the interpretation placed upon the constitution by one of the co-ordinate branches of the government. ${ }^{66}$ Here we find no lack of precedent. ${ }^{67}$ Of these, it will be sufficient to give one typical case, that of Thaddeus Hyatt, in some detail.

In December, 1859 , the Senate by unanimous vote adopted a resolution providing for the appointment of a committee to investigate the seizure of the government armory and arsenal at Harper's Ferry, with instruction to "report whether any and what legislation may, in their opinion, be necessary on the part of the United States, for the future preservation of the peace of the country, or for the safety of the public property." 88

(2) the information would be of use in aid of a petition that had been signed and presented to the governor by members of the houses, asking him to submit the clection frauds for the consideration of the legislature. He therefore held that the houses had authority to conduct the investigation, but he favored the discharge on the ground that refusal to answer questions before a committee was not contempt of the house-a position which derives little or no support either from reason or from the decided cases. The third member of the court, Associate Judge Prendergast, favored remanding the relators to custody. This was undoubtedly the correct holding. In addition to the reasons given by Judge Harper to sustain the jurisdiction of the houses to make the inquiry, Judge Prendergast called attention to the fact that the governor had asked for a special appropriation to ferret out and punish violations of the laws, including alleged "irregularities and frauds" at the "recent election on the proposed amendment," thus calling for specific legislation on the very question proposed to be investigated. He further pointed out that in addition to refusing to answer questions before the committees, the relators had been called before the houses, the one before the house and the other before the senate, and had there again refused to answer the questions. In view of these facts, the case, aside from the party strife involved, was as clear a case of contempt as one could expect to find.

* For cases in which long established practice or custom of the legislative and executive branches of the government have been given controlling weight, see Stuart v. Laird, I Cranch 299,309 (U.. S., 1803); The Laura, II4 U. S. 4II, 415 (1884) ; Field v. Clark, 143 U. S. 649,683 (I891); McPherson v. Blacker, 146 U. S. I, 36 (1892); Union Bridge Co. v. United States, 204 U. S. 364,380 (I906) ; United States v. Midwest Oil Co., 236 U. S. 459, 474 (I915).

" 3 Hinds. Precedests, Ch. liii, contains many cases where witnesses were haled before one branch of Congress or the other, in custody of the scrgeant-at-arms, to show cause why they should not be punished for contempt for failure to appear when summoned or for refusa' to answer questions or to produce documentary evidence. 74.

"Cong. Globe, Part I, 36th Cong. Ist Sess., p. 141; 3 Hinds, Precedents, 
In the course of the inquiry Thaddeus Hyatt, of New York, was summoned to appear before the committee, but refused. Thereupon the Senate adopted by a vote of 43 to 12 a resolution directing the president of the Senate to issue his warrant for the arrest of Hyatt. He was brought before the Senate, where he refused to answer the questions put to him. The Senate, after a long and exhaustive discussion of the case, much of which concerned its own jurisdiction to punish in such a case, adopted, by a vote of 44 to Io, the following resolution:

"That the said Thaddeus Hyatt be committed by the Sergeant-at-Arms to the common jail of the District of Columbia, to be kept in close custody until he shall signify his willingness to answer the questions propounded to him by the Senate; and for the commitment and detention of the said Thaddeus Hyatt, this resolution shall be a sufficient warrant." 69

This resolution was passed on March 12, 1860, and Hyatt remained in jail until the committee had made its report and had been discharged, when, upon June I5, upon the committee's recommendation, he was discharged from custody. In the debate preceding the adoption of the resolution, and again upon Hyatt's discharge, Senator Sumner, of Massachusetts, delivered a strong argument against the power of the Senate to punish in such a case. This, he contended, was the exercise of a judicial function; but the Senate under the Constitution can exercise judicial power in only three cases: (1) in trying impeachntents, (2) in determining the election or the qualification of its members, and (3) in punishing members for disorderly behavior, or, with the concurrence of two-thirds, in expelling a member.

"In the execution of these powers," said he, "the Senate has the attributes of a court; and, according to established precedents, it may summon witnesses and compel their testimony, although it may well be doubted if a law be not necessary, even to the execution of this power."

“ Cong. Globe, Part 2, p. 1100; 3 Hinds, Precedents, 76. 
It had, also, in self defense, he said, assumed jurisdiction in two other cases: ( I) with regard to the conduct of its servants, as its printer, and (2) "when its privileges have been violated, as in the case of William Duane, by a libel, or in the case of Nugent, by stealing and divulging a treaty while still under the seal of secrecy." 70

-Sumner's argument was effectively answered by several senators, including Senator Fessenden, of Maine, who said:

"The great purpose is legislation. There are some other things, but I speak of legislation as the principal purpose. Now, what do we propose to do here? IVe propose to legislate upon a given state of facts, perhaps, or under a given necessity. IVell, sir, proposing to legislate, we want information. We have it not ourselves. It is not to be presumed that we know everything; and if anybody does presume it, it is a very great mistake, as we know by experience. We want information on certain subjects. How are we to get it? The Senator says, ask for it. I am ready to ask for it; but suppose the person whom we ask will not give it to us: what then? Have we not power to compel him to come before us? Is this power, which has been exercised by Parliament, and by all legislative bodies down to the present day without dispute-the power to inquire into subjects upon which they are disposed to legislate-lost to us? Are we not in the possession of it? Are we deprived of it simply because we hold our powver here under a Constitution which defines what our duties. are, and what we are called upon to do?" 71

From the principle involved and from the foregoing examination of judicial and legislative precedents, one is warranted in saying without hesitation that legislative bodies may properly exercise their contempt powers in procuring information deemed necessary for intelligent law making. No case has been found where any court has held that there was no power in a legislative assembly to compel testimony in a matter concerning which it had power to legislate.

\footnotetext{
"Cong. Globe, 36th Cong., Ist Sess., pp. 3006-3007.

"Cong. Globe, 36th Cong,, Ist Sess, p. I10.
} 


\section{E. The Informing or Educative Function}

This function of legislative bodies is very broad and general and no judicial decision has been found definitely passing on the question whether a legislative assembly can punish a witness who refuses to testify in a hearing where the only purpose in view was the vindication of the good name of a public officer 72 or the stimulating of efficiency in government by having its processes carried on under the bright light of publicity, or the enabling of the stockholders in the cnterprise, the voters, to see and know as much as possible about how their business is being performed. or, lastly, the driving from the service an unworthy officer by the compelling force of public opinion, as a less cumbersome and expensive mechanism than impeachment. ${ }^{\text {i3 }}$ This function, or group of functions, whose value was recognized by the fathers, as the debates on the early investigation resolutions clearly show, has grown enormously in importance with the general diffusion of education, the great development of the newspaper press, the constarit widening of the right of suffrage, and the direct participation of larger numbers of the people in the affairs of government. So much is this true that writers on government are giving more and more attention to what has been called "government by public opinion." Napoleon is quoted as saying that "opinion rules everything," 74 and Hume puts the same thought in this form:

"A possible exception is to be found in the case of Ex parte Caldwell, 138 Fed. 487 (C. C., 1905), where an inferior Federal Court held that the purpose of the inquiry was to vindicate the Governor. The case was reversed on another ground in Carfer, Sheriff, v. Caldwell, 200 U. S. 293 (1905). However, the vindication of the good name of the legislature has been recognized as a proper ground for carrying on an investigation. See the quotation from In re Chapman, p. 794, supra.

${ }^{r} \mathrm{~A}$ dictum adverse to the exercise of such a power is found in Ex parte Daugherty, 299 Fed. 620, 639 (D. C., 1924), where District Judge Cochran said:

"The Senate has no power to impeach any federal officer at the bar of public opinion, no matter what possible good may come of it. It is not within its province to harass, annoy, put in fear, render unfit, or possibly drive from office any such officer, high or low, by instituting such impeach-

"Dicey, Law and Public Opinion in ExGland, p. I (note). 
"As force is always on the side of the governed, the governors have nothing to support them but opinion. It is, therefore, on opinion only that government is founded." 75

Bryce devotes more than one hundred pages of his. "American Commonwealth" to the subject of "Public Opinion" as a power in government, ${ }^{76}$ explaining the ever-increasing part that it plays in our country in the following significant fashion:

“. . The phrase 'government by public opinion' is most specifically applicable to a system wherein the will of the people acts directly and constantly upon its executive and legislative agents. A government may be both free and good without being subject to this continuous and immediate control. Still this is the goal towards which the extension of the suffrage, the more rapid diffusion of news, and the practice of self-government itself necessarily lead free nations; and it may even be said that one of their chief problems is to devise means whereby the national will shall be most fully expressed, most quickly known, most unresistingly obeyed. Delays and jerks are avoided, friction and consequent waste of force are prevented, when the nation itself watches all the play of the machinery and guides its workman by a glance. Towards this goal the Americans have marched with steady steps, unconsciously as well as consciously. No other people now stands so near it." 77

As a means of stimulating, educating, and guiding this enormously important factor in our government, public opinion,

"Huak, Essays, Vol. I, Essay IV, p. 110, quoted in Dicey, op. cit., p. 2.

${ }^{70}$ Vol. II, Part IV, pp. 25I-376.

"BRYCE, A serican Com Moniwealth, Vol. II, Pt. IV, p. 267. More than thirty years later, this great student of our institutions, in his last book said:

"In saying that Public Opinion is the real ruler of America, I mean that there exists a judgment and sentiment of the whole nation which is imperfectly expressed through its representative legislatures, is not to be measured by an analysis of votes cast at elections, is not easily gathered from the most diligent study of the press, but is nevertheless a real force, impalpable as the wind, yet a force which all are trying to discover and nearly all to obey. As Andrew Marvell wrote:

"There is on earth a yet diviner thing, Veiled though it be, than Parliament or King.'

"In and through it, not necessarily at any single given moment, but in the long run, irrespectively of temporary gusts of passion, the conscience and judgment of the people assert themselves, overruling the selfishness of sections and the vehemence of party."-MODERN DEMOCRACIES, Vol. II, p. 122 (1921). 
the power of Congress to inquire, to investigate, to turn on the light, is of supreme importance. Nowhere has this function of Congress been more lucidly stated than by former President Woodrow Wilson in his work on "Congressional Government":

"Quite as important as legislation is vigilant oversight of adninistration; and even more important than legislation is the instruction and guidance in political affairs which the people might receive from a body which kept all national concerns suffused in a broad daylight of discussion.

"The inquisitiveness of such bodies as congress is the best conceivable source of information. Congress is the only body which has the proper motive for inquiry, and it is the only body which has the power to act effectively, upon the knowledge which its inquiries secure.

"It is the proper duty of a representative body to look diligently into every affair of government and to talk much about what it sees. It is meant to be the eyes and the voice, and to embody the wislom and will of its constituents.

The informing function of Congress should be preferred even to its legislative function." 78

In view of the importance of this informing or inquisitorial function of Congress and of the state legislatures, it may well be doubted that any good reason can be shown why they should not have the unhampered use of the power necessary to make it effective, the power to compel unwilling witnesses to disclose disagreeable facts. That there is possibility of occasional abuse for partisan purposes, and that sometimes private matters are unduly exposed to the public gaze, is perhaps inevitable in a government of fallible men, but it must not be forgotten that the injuries done in these ways are infinitesimal compared to the evil consequences that would result from depriving the people's representatives of the power to know all there is to be known about the conduct of the public business, or from hampering them in getting at the facts, by a narrow legalistic attitude on the part of the courts.

That Congress has from the very-beginning claimed and exercised the power to inquire into all affairs of the government,

"Wilson, CoNgressional Govern Ment, pp. 297-303. 
whether any immediate action was contemplated or not, is abundantly proven by the records and debates. In addition to the instances previously noted, as the Reuben M. Whitney case in 1837, a few others are given in the footnote. ${ }^{79}$.

The following cases in which one or the other house of Congress has ordered investigations under its broad inquisitorial powers are collected in an editorial note, 38 HARv. L. REv. 234, 237, n. 28 (1929) :

"In 1792, three years after the Constitution went into effect the House passed a resolution that a committee be appointed to inquire into the cause of the failure of the expedition under General St. Clair, and that the committee be empowered to call for such persons, papers, and records as may be necessary to assist their inquiries.' Before the resolution was passed, there was an extended debate in which the constitutionality of the investigation was discussed. The resolution was passed by a vote of 44 to 10. See 3 Annals of Congress, 490 et seq.; 3 Hinds, Precedents, \& 1725.

"In 1810, the House passed a resolution that a committee be appointed to inquire into the conduct of General Wilkinson and determine the truth of allegations that he had received money from the Spanish Government and had been involved in a conspiracy with Aaron Burr. The committee was empowered to compel testimony. The resolution did not indicate that legislative action was contemplated. The proponents of the resolution declared that Congress had not only the power to inquire with a view to future legislation, but also the power to carry on an investigation to inform the legislators and the nation regarding the activities of the executive departments. See 21 Annals of Congress, 1606, 1727; 3 HiNDS, op. cit., \$1727.

"In I816, the House adopted a resolution that a committee be appointed to inquire into the state of accounts of James Thomas, late a quartermastergeneral of the United States, and empowered the committee to send for persons and effects. See 29 Annals of Congress, $1199 ; 3$ Hrnds, $\$ 1742$.

"In 1818, the House adopted a resolution that a committee be appointed 'to inquire whether the clerks in the administrative departments of the government had conducted themselves improperly in performing their official duties.' Objections that the House was assuming power over the executive were answered by declarations that the House was the grand inquest of the nation. This investigation was not for the purpose of gaining information that might be used in impeachment proceedings. See 32 Annals of Congress, 1649; 3 HINDS, § 1729.

"In 1819, the House passed a resolution that 'a committee be appointed to inquire whether money appropriated by Congress had been used to support an army raised without authority of Congress.' See 35. Annals of Congress, 717; 3 Hinds, $\$ 1730$.

"In I824, the House investigated, on application of the United States minister to Afexico, a controversy between him and the Secretary of the Treasury. The committee appointed was given power to compel testimony. See 42 Annals of Congress, 243I-2455; 3 Hinds, \& 1741.

"In 1837, upon resolution of the House, a committee empowered to send for persons and papers was appointed to investigate the relations of the Treasury Department to the banks in which public money was deposited. See 3 Cong. Globe, 69; 3 Hinds, \$ 1733.

"In 1858, the House appointed a committee to investigate the accounts of 'the late superintendent of public printing' and empowered the said committee to send for persons and papers. ?io legislative intent was manifest Two witnesses who refused to appear before the committee were, upon warrant issued by the House, arrested by the Sergeant-at-Arms. See 48 Cong. Globe, 194, 1039, 1090, 1193, 1238; 3 Hinds, $\$ \$ 1675,1676$. 


\section{F. Basis of Judicial Reversal of Legislative Contempt Cases}

There is a well-established presumption in favor of the legality and regularity of official action, and especially does this presumption exist where the action under review is that of a coordinate branch of the government. This presumption has always been recognized by the courts with reference to statutes. Chief Justice Waite has said that "èvery possibible prestumption is in favor of the validity of a statute, and this continues until the contrary is shown beyond a reasonable doubt. One branch of the government cannot encroach on the domain of another without danger. The safety of our institutions depends in no small degree on a strict observance of this salutary rule." 80 The same presumption is usually recognized by the courts with reference to the exercise of the contempt powers of legislative bodies. Thus, the New York Court of Appeals has said:

"We are bound to presume that the action of the legislative body was with a legitimate object, if it is capable of being so construed, and we have no right to assume that the contrary was intended. The same principle which renders it the duty of the court to hold legislative action illegal when it unduly encroaches on the province of the judiciary, forbids

"In 186r, the Senate and the House passed a joint resolution that a committee of three members of the Senate and four members of the House be appointed to inquire into the conduct of the Civil War and be empowered to send for persons and papers. See 57 Cong. Globe, 29, 40; 3 Hinds, $\$ 1728$.

"In I879, a committee of the House was appointed to investigate the conduct of the Superintendent of Elections of New York, an official appointed by the United States Circuit Court and not removable by empeachment. See 8 Cong. Rec., 127, 175; 3 HrNDs, § 1747.

"Compare the congressional action which called into being the wellknown Covode committee. In Ma:ch, 1860, the House passed a resolution calling upon the Speaker to appsint a committee to investigate whether the President or any other officer of the government had by improper means sought to influence the action of Congress. After the appointment of the committee and a protest by President Buchanan, the House passed a further resolution declaring that the President is subject to investigation by the House. See 51 Cong. Globe, 997, 1434; 2 Hinds, \& 1596."

- Sinking Fund Cases, 99 U. S. 700, 718 (18;8). See also Chief Justice Marshall in Fletcher v. Peck, 6 Cranch 87, 128 (U. S. 1810): ("The opposition between the Constitution and the law should be such that the judge feels a clear and strong conviction of their incompatibility with each other"); and Mr. Justice Washington in Ogden v. Saunders, 12 Wheat. 213 (U. S., 1827) : ("It is but a decent respect due to ... the legislative body by which any law is passed, to presume in favor of its validity, intil its violation of the Constitution is proved beyond all reasonable doubt.") 
interference by the latter with the action of legislative bodies or the exercise of their discretion in matters within the range of their constitutional powers." 81

This principle is so obviously sound that it is surprising to find the courts apparently forgetting it occasionally, and reversing the judgment of a legislative assembly when there clearly was ground upon which it could be sustained. Take, for example, the case of State ex rel. Rulison ' '. Gaymon. ${ }^{82}$ In that case the two houses of the state legislature appointed a joint committee to investigate charges of corruption in the government of the City of Cincinnati, and to report its findings "with such recommendations for future legislation and amendment to existing legislation as the disclosures of the said committee may warrant." On the face of it, this seems to be a perfectly proper and usual method of acquiring useful information on a subject within the competence of the legislature. But the court not only did not indulge in any presumption in favor of the action of the two chambers, but, setting at naught the purpose as expressed in the resolution, it declared "that the resolution itself shows that it was not, in good faith, passed for the purpose of remedial legislation." The court says that "the language of the preamble is intemperate, illtimed and . revolutionary. If sanctioned by the courts the dominant political party will be licensed to prefer, at each recurring election, charges of crime against citizens of any community of which its adversary has control and to hear and determine the same." It inquires "What legislation is proposed to meet a situation like this if found to exist?" and at once answers the question with an astonishing air of finality and prescience: "None whatever, and none could under such conditions be suggested that would be more effective than the present'statutes. The efficiency of all law and especially criminal law lies in the certainty of its enforcement, and it would be a fruitless task to pass numerous criminal statutes when existing statutes upon the same subjects with ample penalties are violated with impunity."

"McDonald v. Keeler, 99 N. Y. 463, 487, 2 N. E. 615 (1885).

31 Ohio Cir. Ct. Rep. 59 (I908). 
That is, of course, an extreme case, but it serves to emphasize the fact that sometimes judges undertake to substitute their judgment of facts and remedies for that of the legislative bodies to whose judgment and discretion the matter is committed, and to say that because they' cannot see any appropriate legislative remedy, none exists. Another case of this kind is Pcople cro rel. Subold $v . W e b b,^{83}$ in which a lower New York Court held that the house had no authority to investigate charges of fraud growing out of the repairing of the capitol building at Albany, though it admitted that "if, by this declaration of the purpose of the investigation, the court could see any field open for legislation growing out of the investigation, it would clearly be the duty of the court to give full effect to that declaration."

Still another case in point is In re Barnes, ${ }^{84}$ in. which the Court of Appeals of New York substituted its judgment for that of the house of representatives as to the quantum of evidence to be adduced on a particular subject under investigation.

The case that has done more than any other to unsettle the law governing legislative contempts is that of Kilbourn v. Thompson. ${ }^{85}$ This far-reaching effect has been due more to the dicta in the case and to the antagonistic tone of the opinion than to the actual decision. An attempt was made in the preceding article ${ }^{85 *}$ to show the error in Mr. Justice Miller's dictum that English parliamentary and judicial precedents on this subject have no value for us. Attention has also been called to the fact that the court expressly reserved for future consideration the question as to the use of the contempt power to compel the production of testimony to be used merely in aid of the law-making power. All that the case decided was that the House of Representatives, in the particular case, did not have jurisdiction to make the inquiry, and therefore had no authority to imprison Kilbourn for refusal to produce the documents called for by the committee.

\footnotetext{
5 N. Y. Supp. 855 (1889).

is 204 N. Y. 108, 97 N. E. 508 (1912).

"Supra, note 20 .

is See 74 U. of PA. L. Rev. 692 et seq.
} 
The facts of the case may be briefly stated as follows: The banking house of Jay Cooke \& Co. became bankrupt owing to the United States government a considerable sum of money, resulting as was stated in the preamble to the resolution of the House providing for this investigation, "from the improvident deposits made by the Secretary of the Navy of the United States with the London branch of said house of Jay Cooke \& Co. of the public moneys." The preamble recites that the trustee in bankruptcy had recently made a settlement of the interest of the defunct bank in a certain real estate pool in the District of Columbia, with the bank's associates in the pool, to the disadvantage of other creditors, including the United States, and that the courts were powerless by reason of that settlement to afford adequate redress to these creditors. A committee was, therefore, appointed to inquire into "the matter and history" of the real estate pool and the character of the settlement, with the amount of property involved in which Jay Cooke \& Co. were interested, and the amount paid or to be paid in said settlement. Kilbourn was summoned before the committee but refused to answer questions and produce documents called for. The House committed him for contempt and he later brought an action against Thompson, the sergeant-at-arms, for false imprisonment. Defendant's special plea setting out the foregoing facts was held bad on demurrer, on the ground, as stated above, that the House had no jurisdiction to make the investigation. The proper procedure for the collection of debts due to the United States, said the court, is by a resort to courts of justice. The District Court for the Eastern District of Pennsylvania had taken jurisdiction and had the whole subject before it at the time the investigation was ordered. If any fraud were discovered as a result of the inquiry, Congress would be powerless to deal with it, the courts alone having the power to set aside transactions of that character. There was no intimation in the preamble or the resolution that the House was seeking to exercise the power of impeachment or that any legislation was in contemplation. The court therefore concluded that 
it was a fruitless investigation and a needless prying into the private affairs of the citizen.

It is not easy to justify the case on the basis of either logic . or precedent. It certainly does not indulge in any sort of presumption favorable to the legislative action involved. Because the preamble does not definitely avow a purpose within the competence of the house, the court jumps to the conclusion that there is no such purpose. The house is not permitted to get the facts first and decide upon the remedy in the light of full knowledge. The court says that if "any" purpose had been avowed to impeach the secretary, the whole aspect of the case would have been changed." Is not this an admission that the subject matter was within the jurisdiction of the House, and that the fatal defect was a failure to state the purpose in explicit terms? Would it not have been a very simple matter for an inchoate purpose of impeachment, held in solution in the legislative mind at the beginning, to become a definite and fixed purpose if the facts found should warrant it? Is it not a fact that most impeachments result from investigations that are not in the beginning labeled with the sinister word "impeachment"? Why blacken the character of a public official by the use of such a word until sufficient facts are found to justify it?

Again, may it not be possible that such an investigation would show the need of legislation to prevent future secretaries from making "improvident deposits," or to limit the power of trustees in bankruptcy to prefer some creditors over others? How does it come about that the court can know beforehand whether a situation may not be developed by inquiry calling for legislation? In this connection, it should not be overlooked that the real estate pool in question existed in the District of Columbia over which Congress possesses all the legislative powers elsewhere distributed between the state and the national legislatures. Might it not be possible that the proposed inquiry would show the need of legislation for the regulation of such pools in the District? And is it not possible that the House had it in mind, without any intention of legislating or of impeaching the Secretary of the Navy, to make the incident a means of teaching the public 
and especially future secretaries and other officials an important lesson in the handling of public funds?

The demand of the court in this case that the purpose of the investigation and the use to be made of the facts gained shall be definitely stated beforehand, is in striking contrast to the broadminded view taken by the Supreme Court in the later case, In re Chapman. There Chief Justice Fuller says:

"What the Senate might or might not do upon the facts when ascertained, we cannot say, nor are we called upon to inquire whether such ventures might be defensible, as contended in argument. . . . Nor will it do to hold that the Senate had no jurisdiction to pursue the particular inquiry because the preamble and resolutions did not specify that the proceedings were taken for the purpose of censure or expulsion, if certain facts were disclosed by the investigation. The matter was within the range of the constitutional powers of the Senate. . . . We cannot assume on this record that the action of the Senate was without a legitimate object, and so encroach on the province of that body. Indeed, we think it affirmatively appears that the Senate was acting within its right, and it was certainly not necessary that the resolutions should declare in advance what the Senate meditated doing when the investigation was concluded." 86

The Kilbourn case, then, is vulnerable in at least three particulars: (I) it does not indulge in any presumption in favor of the legality of the action of the legislative body; (2) it regards the failure of the House to state what particular use was to be made of the facts to be gathered as a fatal defect, and (3) the court assumes to substitute its judgment as to the existence vel non of some sort of legislative remedy for the judgment and discretion of the legislature to which the matter is committed by the constitution. The subject under investigation, viewed in the large, certainly was within the competence of the House, and that body should have been allowed to scrutinize it from every angle and to exercise its legitimate functions unhampered. The dan-

" 166 U. S. 661, 669-670. For several state cases in harmony with the views here expressed, see pp. 793-4, supra. 
ger that some slight injury might have been done to a few individuals in causing their private affairs needlessly to be exposed to the public gaze is infinitesimal compared to the right of the people of the nation to have their representatives free from annoying judicial interference in the discharge of their important duties.

We come now to the case which gave occasion to the present inquiry, the case of Ex partc Daughcrty, ${ }^{87}$ in which the Federal District Court for the Southern District of Ohio discharged the relator on the ground that the Senate had no power to carry on the investigation then under way. The facts in the case may be briefly stated as follows: On March I, 1924, the Senate adopted a resolution providing for the selcction of a committee of five, with power to send for persons and papers, to investigate and report upon the alleged failure of the Attorney General "to prosecute properly violators of the Sherman Anti-Trust Act and the Clayton Act against monopolies and unlawful restraints of trade"; also "the alleged neglect and failure to arrest and prosecute" certain named individuals for conspiracy to defraud the government in connection with the leasing of the naval oil reserves and the management of the veterans' bureau; and "the alleged neglect and failure" to perform a number of other important duties of his office therein named. In the course of the investigation the committee became convinced that valuable information might be obtained from the records of a certain bank in Ohio, of which the Attorney General's brother, the relator in this proceeding, was president. But when summoned, relator refused to appear and produce the books and papers called for. Thereupon the Senate adopted a preable and resolution which, after reciting the foregoing facts and declaring that "the appearance and testimony of said M. S. Daugherty is material and necessary, in order that the committee may properly execute the functions imposed upon it, and obtain information necessary as

299 Fed. 620 (D. C., 1924). This case was decided by Judge Andrew M. j. Cochran, District Judge for the Eastern District of Kentucky, sitting by designation especially to hear this case. 
a basis for such legislative and other action as the Senate may deem necessary and proper," directed the President of the Senate to issue his warrant for the arrest of the relator that he might be brought before the bar of the Senate "then and there to answer such questions pertinent to the matter under inquiry as the Senate may order the President pro tempore to propound." When arrested in Ohio under the warrant provided for in this resolution, relator sued out a writ of habcas corpus and was discharged from the custody of the sergeant-at-arms.

It will be noted that relator was not haled before the Senate to show cause why he should not be punished for refusing when first summoned to appear and produce the books called for. There was no intination that the Senate proposed to punish him for a past offence, but its action was only an attempt to secure attendance and testimony in the future. It should also be noted that the Senate indicates the use, or at any rate, one use to which it proposed to put the information gained- "for such legislative and other action as the Senate may deem necessary and proper."

The court, in the opinion, does not consider it necessary to decide whether compulsory process may be used to secure information to be used solely in aid of legislation, for the court questions the good faith of the Senate in stating in the preamble that the information is to be used as a basis for legislative action. Thus the court says:

"The extreme personal cast of the original resolutions; the spirit of hostility towards the then Attorney General which they breathe; that it was not avowed that legislative action was had in view until after the action of the Senate had been challenged; and that the avowal was then coupled with an avowal that other action was had in view-are calculated to create the impression that the idea of legislative action being in contemplation was an afterthought. That there is a disposition somewhere in connection with this investigation to stretch things appears from the sweeping demand to produce documents made on petitioner by the first summons of the Committee." 88

$\approx 299$ Fed. 638 
In this way, by questioning the good faith of the Senate's declaration of a legislative purpose, the court avoids a troublesome question, merely remarking in passing that "I have very serious doubt as to the existence of such power." It next considers the second part of the Senate's declaration of purpose. What "other action," it asks, "could the Senate take? Certainly not impeachment, for the House alorle can prefer impeachment charges." "Then," said the court, "I would not be warranted, on the face of things before me, to hold that it is merely to besmirch the former Attorney General and to pillory him, or that there is some other sinister purpose behind the investigation." The idea had been suggested on argument that the purpose might be to impeach the Attorney General at the bar of public opinion, but the court declares that the Senate has no such power. ${ }^{80}$.

The court then reaches the conclusion that the action of the Senate is wholly void as being the exercise of a judicial function "and power to exercise that function in such a case as we have here, has not been conferred upon it expressly or by fair implication. What it is proposing to do is to determine the guilt of the Attorney General of the short-comings and wrongdoings set forth in the resolution. It is 'to hear, adjudge, and condemn.' In so doing it is exercising the judicial function." ${ }^{\text {oo }}$ A little further on the court says:

"What the Senate is engaged in doing is not investigating the Attorney General's office; it is investigating the former Attorney General. What it has done is to put him on trial before it. In so doing it is exercising the judicial function. . . . As I view the matter, the Senate in its action has usurped judicial power and encroached upon the prerogative of the House of Representatives." 21

Such, then, is the gist of the court's opinion. It quotes and relies upon the Kilbourn case, and has all the weaknesses of that

- The language on this point is quoted in note 73.

${ }^{\infty} 299$ Fed, page 639 .

"Id., page 640. The use of the term "former Attorney General" in this quotation may be misleading unless it be recalled that Attorney General Daugherty resigned from the cabinet after this proceeding was begun and before the opinion was written. 
case, which the present writer has attempted to point out above, ${ }^{02}$ and some others besides. Like that case, it indulges in no presumption in favor of the legislative action under review. In that case, it will be recalled, the court held that it was a fatal weakness for the House to fail to state a lawful use to which it proposed to put the information sought to be gained by the inquiry, but that "the whole aspect of the case would have been changed," if the House had avowed any intention to impeach the Secretary of the Navy. In the later case, In re Chapman, the rule in the Kilbourn case was rejected and the court said that if the Senate had jurisdiction of the subject matter it was immaterial whether the resolution stated any use expected to be made of the information or not. ${ }^{93}$ But now comes this district court and rejects the rule in both cases, impugns the good faith of the Senate, sets aside the purpose declared by that body as an "afterthought," and intimates that there is "a disposition somewhere in connection with this investigation to stretch things." Not only does it refuse to consider seriously the Senate's declaration of a legislative purpose, refusing for that reason to consider whether a legislative purpose alone would be a legal ground for compelling the giving of testimony, but it goes further and declares that no other purpose that the Senate might assign would justify its action, the court saying:

"That the Senate has in contemplation the possibility of taking action other than legislation as an outcome of the investigation, as thus expressly avowed, would seem of itself to invalidate the entire proceeding." ${ }^{84}$

The position of the court seems to be that it will not inquire whether legislation is a sufficient purpose, for the reason that the Senate put that forward as an "afterthought" to cover up its real purpose, and that it was not worth while for the Senate to state its real purpose for any such purpose, no matter what it might

\footnotetext{
* See pp. 820-1, supra.

"See quotation from Chief Justice Fuller's opinion, p. 820, supra.

M 299 Fed. 639
} 
be, "would seem of itself to invalidate the entire proceeding." The reason, if reason there can be for such a position, is to be found in the fact that the court looks upon the proceeding as a sort of criminal trial. "What it is proposing to do is to determine the guilt of the Attorney General," said the court. "What the Senate is engaged in doing is not investigating the Attorney General's office; it is inrestigating the former Attorney General. What it has done is to put him on trial before it."

This is certainly a surprising position for the court to take. That when you are inquiring whether the Attorney General had failed in the discharge of his official duties, whether he had failed or neglected or refused to prosecute violators of the law, wrongdoers in high official and political circles, and whether or not, if such neglect or refusal were found to exist, it was the-result of any yielding to improper personal, political, or financial influences - that in making such an inquiry you are trying the Attorney General and not investigating the management of his department, is, to say the least of it, a most novel doctrine in public law. How else could an investigation of a department be made? If this be not a proper investigation of a department, even though the official character of members of the staff may suffer by the disclosures, it would be difficult to understand how such an investigation could be conducted.

One further point is to be noted. The opinion quotes a passage from counsel's brief, strongly contending for the right of the Senate to investigate fully every department of the government as a prerequisite to intelligent legislation in granting supplies for the support of the public service." With this the court says it fully concurs, but it hastens to add that "there would seem to be no reason why the information referred to therein cannot be obtained without calling on outsiders." Here, then, we have another peculiar restriction upon the power of the Senate. It has a perfect right, and it is its duty to inform itself fully before expending the public funds, and it may have compulsory process to secure the testimony of public employees; but it may not resort to "outsiders." Such a rule amounts to saying that if you wish to know whether A has conducted his department efficiently; or 
has been guilty of neglect of duty or of outright dishonesty, you may ask him or one of his subordinates, but you may not call before you the men on the outside who may have used $A$ as a tool for securing all sorts of special favors at the hands of the government. Their books may contain the most conclusive evidence of corruption in the administration of a great public trust, but those books must remain sealed to the people's representatives because to look at them would be to try A for "the shortcomings and wrongdoings set forth in the resolutions." Surely if the Senate has power to inquire at all, it has power to push the inquiry into any quarter where the truth may be found. Anything less than that would be to grant power and at the same time withhold the means of making it effective.

In the opinion of the present writer the Senate's investigation can be justified on a number of grounds. In the first place, it is too well settled to be questioned that either branch of the legislature has a right to investigate the administration of the various departments of the government. It is a practice universally followed. In the second place, the Senate had a right to carry on the investigation as a basis of legislation. This legislation, one would suppose, could have taken on many forms, such as appropriating or withholding funds for the support of the department or certain branches of it; directing the Attorney General, by resolution or special act, to prosecute suits against persons believed to have been guilty of violating the law or of committing frauds upon the government; and strengthening the statutes which define the duties of the Attorney General and his staff. Doubtless other legislative possibilities would suggest themselves to members of the Senate when the facts were laid before them. Then, to, aside from legislation there is a proper service which the Senate may perform by such an investigation, the very important one of informing the voters and the public generally as to the way in which their business is being conducted. As has elsewhere been pointed out, this function has received far too little recognition at the hands of the courts. No action that the houses could take would have had a greater reaction in toning up the entire public service on the one hand, or, on the 
other, in preparing the voting public for a more intelligent participation in public affairs.

In conclusion it should be noted that the Daugherty case may readily be distinguished from the two cases in which the Supreme Court has heretofore decided against the contempt power asserted by the House. In the Kilbourn case, the subject under investigation was, in the opinion of the court, a purely private matter over which the House could exercise no jurisdiction; in the Dangherty case, this is certainly not true for the subject under investigation was the administration of a department of the government. There a federal district court had taken jurisdiction of the whole matter and had not finally disposed of it; here no court action, either state or federal, was involved. There the resolution failed to state any use to be made of the information to be gained; here the purpose is definitely stated in the Senate's resolution. The other case, Marshall i. Gordon, involved a very peculiar state of facts that finds no resemblance or parallel in any way in the Daugherty case. In the Marshall case the court could reasonably conclude, as it did, that the act charged did not directly obstruct the proceedings of the House and was a matter to be dealt with by the criminal courts. In the Daugherty case, we have a contumacious witness whose refusal to appear and produce documents is a direct and effectual obstruction of the proceedings of the legislative body. It is clear that neither reason nor precedent called for a denial by the court of the power asserted by the Senate.

\section{Summary and Conclusion}

From the foregoing discussion the following conclusions seem to be fully warranted:

I. While some of the privileges of the houses of the English Parliament are very ancient, many of them, perhaps the most important, especially of the House of Commons, took their rise when the Commons became an important, and, finally, the dominant factor in the government of England during the sixteenth and seventeenth centuries. The right of the House of Commons to vindicate its privileges by punishing, as for contempt, those 
who invaded them was first asserted in the middle of the sixteenth century and by the end of the seventeenth century came to be recognized as the exclusive means.

2. The colonial assemblies in this country modeled themselves after the House of Commons and asserted the same privileges and vindicated them by the same means.

3. In this way the contempt power came to be recognized throughout the English-speaking world, as an essential part, or auxiliary, of legislative power. As such it was conferred as a matter of course and without specific provision upon all legislative bodies created by the fathers of the Revolutionary period. That this was so is fully demonstrated by the practice of the Continental Congress and of the state and national legislative assemblies.

4. Being founded upon necessity and being an inherent part, or auxiliary, of "legislative power," the contempt power was practically unaffected by the introduction of written constitutions recognizing the doctrine of the separation of the powers of government. It was also entirely unaffected by the distribution of the legislative field to the states on the one hand and to the national government on the other. The legislative bodies of each government could use freely the contempt power as an aid to the proper performance of such powers as were assigned to it by our constitutional arrangement.

5. In England the courts will never interfere directly by habeas corpas with the exercise of the contempt power by the two houses, and the speaker's warrant is a complete protection to those who execute it. In the United States the courts assert their right to determine whether the legislative body is acting within its constitutional limits-that is, whether it has jurisdiction to perform some legitimate function in connection with the matter in hand. Granted that the assembly has jurisdiction, the courts will not ordinarily interfere by undertaking to substitute their judgment for that of the assembly as to whether the conduct complained of is in fact contemptuous.

6. The contempt power, being a part of the machinery of a legislative assembly, can be used by it in aid of any of its func- 
tions, whether defensive, judicial, legislative, or inquisitorial. In this connection, the distinction sometimes made between the " $\mathrm{ju}$ dicial" and the other powers of legislative bodies is essentially unsound.

7. As either house of Congress has an undoubted right to investigate the management of any department of the federal governmeint, the Senate in the Daugherty' case was clearly within its jurisdiction in calling for documents that it believed contained important information bearing on the administration of the Department of Justice. The unfortunate interference by the District Court coupled with the subsequent destruction of the documents sought by the Senate has, rightly or wrongly, left in the public mind a suspicion amounting almost to positive conviction that a serious public scandal has been hushed up and the wrong-doers have gone unwhipped of justice. Public policy would seem to require that only in the clearest cases of want of jurisdiction and of oppression should the courts interfere with legislative investigations.

Cambridge, Mass.

$$
\text { C. S. Potts. }
$$

